\title{
Salt, the renin-angiotensin-aldosterone system and resistant hypertension
}

\author{
Tatsuo Shimosawa
}

High salt intake is a risk for developing resistant hypertension, and even under triple therapy with diuretics, an angiotensinconverting enzyme inhibitor/angiotensin receptor blocker and a calcium channel blocker, the volume is occasionally not controlled. In such cases, a mineralocorticoid receptor (MR) antagonist additively lowers the circulating blood volume and blood pressure despite the lower circulating aldosterone level. This mechanism may be explained by the increase in the number of MR under some conditions or the activation of these receptors independent of aldosterone. Future diagnostic tools to evaluate receptor activity may be valuable for the proper diagnosis and choice of therapy. Additionally, basic research has suggested that oxidative stress and the renin-angiotensin-aldosterone system in the brain represent new targets for the treatment of resistant hypertension.

Hypertension Research (2013) 36, 657-660; doi:10.1038/hr.2013.69

Keywords: mineralocorticoid receptor; oxidative stress; rac1; RVLM

\section{INTRODUCTION}

Resistant hypertension is defined as uncontrolled blood pressure (BP) under treatment with at least three drugs, including diuretics, and with all agents prescribed at optimal doses. ${ }^{1}$ A survey showed that 20 $30 \%$ of hypertensive patients require three or more antihypertensive agents and that resistant hypertensives are at high risk for target organ damage. ${ }^{2-7}$ Several factors associated with poor BP control include older age, severe hypertension, chronic kidney disease, female sex, obesity and diabetes mellitus, but the mechanism underlying resistant hypertension remains poorly understood. Several clinical studies have shown that the expansion of the circulating volume, greater cardiac output and/or vascular resistance are pathophysiological features of resistant hypertension and that the most common etiology is excessive salt intake. ${ }^{8}$ Even though these patients are treated with diuretics, how does salt intake overcome the effect of diuretics? Why is salt restriction effective in resistant hypertensives? One possible explanation is that diuretics, with thiazide being the most commonly used, are not fully effective at the clinically used dosage. Older and recent clinical and basic research studies have suggested how excessive salt intake under thiazide treatment leads to resistant hypertension.

\section{THIAZIDE AND VOLUME CONTROL}

Thiazide blocks the sodium-chloride channel (NCC) at the distal nephron, thereby inhibiting sodium resorption and reducing the circulating volume. A previous clinical study revealed that $50 \mathrm{mg}$ of hydrochlorothiazide can reduce the circulating volume for only few days after its administration, with the circulating volume almost returning to the baseline, the extracellular volume remaining suppressed and the BP being maintained lower than the baseline. ${ }^{9}$

These results suggested that thiazide treatment cannot replace dietary sodium restriction therapy, which decreases both the circulating and extracellular volume. Moreover, in cases of resistant hypertension with advanced chronic kidney disease, the glomerular filtration rate $\left(<30 \mathrm{ml} \mathrm{min}^{-1}\right)$ and medullary blood flow are impaired, and thiazide cannot block the NCC fully because it cannot be delivered effectively to the proximal tubule, where thiazide dissociates from its binding protein and is excreted to the tubules to reach the NCC at the distal tubule.

In addition to these issues regarding thiazide, when considering the sodium metabolism in the kidney from the proximal tubules to the collecting ducts, there are several sodium exchangers, and $60 \%$ of sodium is reabsorbed in the proximal tubules but $<20 \%$ is reabsorbed in the distal nephron. Therefore, even after the complete inhibition of the NCC, dietary salt can be reuptaken up by other channels. To control blood volume, loop diuretics and aldosterone blockers are required. Indeed, clinical studies have shown that the addition of an aldosterone antagonist additively lowers BP in resistant hypertensives. ${ }^{5,10,11}$

\section{ALDOSTERONE AND SALT-RELATED RESISTANT HYPERTENSION}

Classically, the role of aldosterone in hypertension is to activate the epithelial sodium channel $(\mathrm{ENaC})$ in the distal nephron to promote sodium reuptake. Recently, the aldosterone receptor in the blood 
vessel was reported to also have an important role in the development of hypertension (Figure 1). ${ }^{12}$ A study in blood vessel-specific mineralocorticoid receptor (MR)-deficient mice revealed that MR can increase the expression of voltage-gated calcium channels, which raises the peripheral resistance. However, renal MR activity, as evaluated by the transtubular potassium gradient (TTKG), could not indicate the effectiveness of the add-on therapy of an MR antagonist in hypertensives. ${ }^{13}$ Under high salt intake, the systemic renin-angiotensin-aldosterone axis is suppressed. In most cases of resistant hypertension, renin-angiotensin inhibitors (angiotensinconverting enzyme (ACE) inhibitors, angiotensin II receptor antagonists or renin inhibitors) are used, and plasma aldosterone levels are not high. Even under these conditions, aldosterone receptor blockade is effective in lowering BP.

The effectiveness of MR antagonists irrespective of the circulating aldosterone levels can be explained by several mechanisms: (1) the number of MRs increases, (2) MR is activated independently of aldosterone and (3) indirect effects of the MR antagonist partly due to sympatho-excitation, oxidative stress and other factors. Under high oxidative stress conditions, such as diabetes or ischemia, the number of MRs increases in the kidney or brain, as shown in studies with rodent models. ${ }^{14,15}$ In humans, the degree of proteinuria parallels MR expression and MR signaling in the kidney. ${ }^{16}$

Both high oxidative stress and impaired renal function are common characteristics of resistant hypertension, and these mechanisms may explain the effectiveness of an MR antagonist as an adjuvant to conventional therapy. In addition to the regulation of MR expression, a recent study showed that MR can be activated in the kidney by rac1, a small G-protein, and that constitutively active racl causes saltsensitive hypertension. ${ }^{17,18}$ The factors that activate racl in the kidney either in hypertension or by dietary salt intake are still

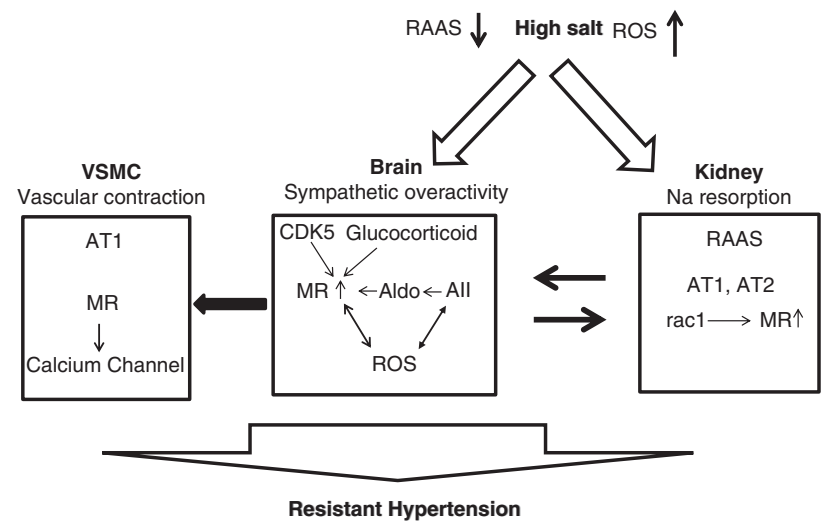

Figure 1 The cross-talk between salt and the renin-angiotensin-aldosterone system in resistant hypertension. Under high salt intake, the reninangiotensin-aldosterone system (RAAS) is suppressed, and oxidative stress (ROS) increases. In the brain, the increased ROS activates the sympathetic tone and local RAAS. The local RAAS increases the ROS in the brain, followed by interactions among angiotensin II (AlI), aldosterone (Ald)/ mineralocorticoid receptor (MR) and the ROS. Efferent sympathetic tone activates the RAAS in the kidney to promote sodium resorption in the kidney and vascular tone in the vascular smooth muscle cells (VSMC). In the kidney, in addition to the local RAAS, the MR is activated by rac1 to further increase sodium resorption. An unknown sensory system may transmit signals to the brain to further increase the sympathetic output. In VSMC, angiotensin II receptor type 1 (AT1) and MR increase contractility by enhancing the calcium influx. unknown. One possible pathway is that local angiotensin II activates Src-kinase, which in turn activates T-cell lymphoma invasion and metastasis 1 (Tiam1); Tiam1 is known to activate several nuclear transcription factors through racl induction. ${ }^{19}$ The rac1-MR pathway might have a role in MR activation in resistant hypertension (Figure 1).

Another study revealed that cyclin-dependent kinase 5 (CDK 5) phosphorylates MR to activate and subsequently increase the transcription of brain-derived neurotrophic factor in the brain. Whether the CDK 5-mediated MR activation in the brain regulates the transcription of other genes closely related to BP control remains unknown, but there are substantial data that MR activation has a pivotal role in controlling BP in the brain.

Aldosterone-mediated MR activation in the brain increases the ouabain-like substance ${ }^{20}$ and the transcription of angiotensinogen, ACE and angiotensin II receptor type 1 (AT1). ${ }^{21,22}$ It also increases oxidative stress or sensitizes the effect of angiotensin II, thereby activating the paraventricular nucleus to induce sympathoactivation. $^{21,22}$ In addition to these factors, MR has been reported to activate sympathetic tone via genomic action at either the rostral ventrolateral medulla (RVLM) ${ }^{23}$ or choroid plexus ${ }^{24}$ in stroke-prone SHR. Serum- and glucocorticoid-induced protein kinase-1 (sgk1) transcription is monitored at the RVLM as a marker of MR activation, although whether $\mathrm{SgK} 1$ directly activates the sympathetic tone has not been demonstrated.

In the choroid plexus, the MR activates $\mathrm{ENaC}$ as in the kidney to increase sodium in the spinal fluid. A small rise of the sodium level in the spinal fluid augments RVLM activity and BP by increasing oxidative stress and activating the MR..$^{23,25}$ Moreover, in the hippocampus under physiological conditions, the non-genomic action of the MR is evoked by glucocorticoid. ${ }^{26}$ Taken together, in RVLM, not only aldosterone but also CDK 5, racl or glucocorticoid may activate the MR to enhance the sympathetic tone and result in the development of sustained hypertension (Figure 1).

One additional effect of an MR blockade in resistant hypertension and salt-induced hypertension is the blocking of oxidative stress. As mentioned above, oxidative stress can enhance MR expression and action, and the blockade of MR suppresses the production of oxidative stress via the inhibition of NADPH oxidase or via a calcium-dependent manner in various organs. ${ }^{27-30}$

In resistant hypertension, diuretics are often used, and a clinical study suggested that an MR antagonist would prevent diureticinduced sympathetic tone. ${ }^{31}$ The precise mechanism with respect to whether the sympatholytic effect occurs via the central MR or renal MR remains unknown, but this additive effect may also explain the effects of an MR antagonist in resistant hypertensives who are treated with thiazide diuretics.

\section{ANGIOTENSIN II AND SODIUM HOMEOSTASIS}

Angiotensin II receptor type 1 and type 2 (AT1 and AT2, respectively) regulate sodium excretion. The AT1 receptor regulates sodium excretion in the proximal tubule and distal tubule. Cross-transplantation of the kidney suggested that the AT1 receptor in the kidney has the dominant role in the $\mathrm{BP}$ response to angiotensin $\mathrm{II},{ }^{32}$ and when angiotensinogen and renin are overexpressed in the proximal tubules, hypertension develops. ${ }^{33}$ Moreover, proximal tubule-specific AT1-deficient mice had lower BP but a similar BP response to salt compared with wild-type mice. In wild-type mice, angiotensin II elevates BP and decreases the level of sodium-hydrogen exchanger (NHE) 3, whereas in proximal tubule AT1-deficient mice, 
NHE3 is further decreased, resulting in a negative sodium balance. These data suggest that angiotensin II blocks the suppression of NHE3 by high BP via AT1 and that therefore pressure-natriuresis is impaired. ${ }^{34}$ The precise mechanism by which NHE3 transcription is regulated by pressure and angiotensin II requires further investigation.

In addition to the effect on the proximal tubules, angiotensin II activates $\mathrm{ENaC}$ in both an acute and chronic fashion. Acute $\mathrm{ENaC}$ activation partly occurs via oxidative stress. ${ }^{35}$ In contrast, the AT2 receptor promotes sodium excretion directly or indirectly by acting on the kidney. ${ }^{36,37}$ A pharmacological study involving the interstitial administration of angiotensin II, III and AT2 receptor blockers revealed that angiotensin II and III induce natriuresis via the AT2 receptor. ${ }^{36}$

The AT1 and AT2 receptors have also been identified in the brain, and the microinjection of angiotensin II into the nucleus in the brain elicits an increase in BP and sympathetic activation via the AT1 receptor. In contrast, AT2 receptor activation induces a potassium channel current by increasing the probability of open channels ${ }^{38}$ in vivo experiments showed that overexpression of the AT2 receptor at RVLM suppressed the sympathetic tone and induced a diuretic effect. ${ }^{37}$ Whether angiotensin III is a ligand for the AT2 receptor in the brain is unknown, but AT2 receptor activation counteracts the AT1 receptor in the control of the circulating volume. ACE inhibitors block angiotensin II production, and therefore, the activation of both AT1 and AT2 is reduced, which, overall, maintains the sodium balance at a neutral level. An AT1 blocker can block sodium resorption in both the proximal and distal nephron directly and via a sympatholytic effect, and together with thiazide, it could result in a negative sodium balance.

Therapeutic doses of an ACE inhibitor, AT1 receptor blocker or renin inhibitor may not be high enough to inhibit either the circulating or locally produced angiotensin II (AII) effect, but $\mathrm{AT} 1 / 2$ receptor signaling may also be regulated independently of AII. ${ }^{39-44}$ The factors in resistant hypertension that can alter AT1/2 receptor activation, such as the bradykinin receptor, eceptor-associated proteins or other proteins, require future research.

\section{PERSPECTIVES}

It is well accepted that an MR blockade should be considered as a pharmacological intervention in resistant hypertensives partly because $\sim 20 \%$ of resistant hypertension comprises undiagnosed primary aldosteronism. ${ }^{45}$ In addition to the failure of a proper diagnosis, recent studies have suggested that circulating aldosterone is not necessarily a marker of MR activation and that even at low aldosterone levels, MR antagonists are effective in lowering BP and protecting target organs. Not only MR but also the AT1 and AT2 receptors could be activated despite the suppression of circulating renin or AII. New diagnostic tools to evaluate the renin-angiotensinaldosterone axis status with respect to their receptor activities, such as the AT1/2 receptors and MR, in the kidney, brain or vasculature in resistant hypertensives may open a new pathway to understand the pathophysiology of resistant hypertension and enable therapies to be tailor-made.

\section{CONFLICT OF INTEREST}

The author received research grant from Japan Science and Technology Agency, Japan Ministry of Education and Science, Merck and Takeda and lecture fee from Novartis and Daiichi-Sankyo.
1 Ogihara T, Kikuchi K, Matsuoka H, Fujita T, Higaki J, Horiuchi M, Imai Y, Imaizumi T, Ito S, Iwao H, Kario K, Kawano Y, Kim-Mitsuyama S, Kimura G, Matsubara H, Matsuura H, Naruse M, Saito I, Shimada K, Shimamoto K Suzuki H, Takishita S, Tanahashi N, Tsuchihashi T, Uchiyama M, Ueda S, Ueshima H, Umemura S, Ishimitsu T, Rakugi H. The Japanese Society of Hypertension guidelines for the management of hypertension (JSH 2009). Hypertens Res 2009; 32: 3-107.

2 Hajjar I, Kotchen TA. Trends in prevalence, awareness, treatment, and control of hypertension in the United States, 1988-2000. JAMA 2003; 290: 199-206.

3 Cushman WC, Ford CE, Cutler JA, Margolis KL, Davis BR, Grimm RH, Black HR, Hamilton BP, Holland J, Nwachuku C, Papademetriou V, Probstfield J, Wright JT Jr, Alderman MH, Weiss RJ, Piller L, Bettencourt J, Walsh SM. Success and predictors of blood pressure control in diverse North American settings: the antihypertensive and lipid-lowering treatment to prevent heart attack trial (ALLHAT). J Clin Hypertens (Greenwich) 2002; 4: 393-404.

4 Black HR, Elliott WJ, Grandits G, Grambsch P, Lucente T, White WB, Neaton JD, Grimm RH Jr, Hansson L, Lacourciere Y, Muller J, Sleight P, Weber MA, Williams G, Wittes J, Zanchetti A, Anders RJ. Principal results of the Controlled Onset Verapamil Investigation of Cardiovascular End Points (CONVINCE) trial. JAMA 2003; 289: 2073-2082.

5 Chapman N, Dobson J, Wilson S, Dahlof B, Sever PS, Wedel H, Poulter NR. Effect of spironolactone on blood pressure in subjects with resistant hypertension. Hypertension 2007; 49: 839-845.

6 Calhoun DA, Jones D, Textor S, Goff DC, Murphy TP, Toto RD, White A, Cushman WC White W, Sica D, Ferdinand K, Giles TD, Falkner B, Carey RM. Resistant hypertension: diagnosis, evaluation, and treatment. A scientific statement from the American Heart Association Professional Education Committee of the Council for High Blood Pressure Research. Hypertension 2008; 51: 1403-1419.

7 Cuspidi C, Macca G, Sampieri L, Michev I, Salerno M, Fusi V, Severgnini B, Meani S, Magrini F, Zanchetti A. High prevalence of cardiac and extracardiac target organ damage in refractory hypertension. J Hypertens 2001; 19: 2063-2070.

8 Gaddam KK, Nishizaka MK, Pratt-Ubunama MN, Pimenta E, Aban I, Oparil S, Calhoun DA. Characterization of resistant hypertension: association between resistant hypertension, aldosterone, and persistent intravascular volume expansion. Arch Intern Med 2008; 168: 1159-1164.

9 Shah S, Khatri I, Freis ED. Mechanism of antihypertensive effect of thiazide diuretics. Am Heart J 1978; 95: 611-618.

10 Nishizaka MK, Zaman MA, Calhoun DA. Efficacy of low-dose spironolactone in subjects with resistant hypertension. Am J Hypertens 2003; 16 (11 Pt 1), 925-930.

11 Nishizaka MK, Calhoun DA. Use of aldosterone antagonists in resistant hypertension. J Clin Hypertens (Greenwich) 2004; 6: 458-460.

12 McCurley A, Pires PW, Bender SB, Aronovitz M, Zhao MJ, Metzger D, Chambon P, Hill MA, Dorrance AM, Mendelsohn ME, Jaffe IZ. Direct regulation of blood pressure by smooth muscle cell mineralocorticoid receptors. Nat Med 2012; 18 : 1429-1433.

13 Jansen PM, Frenkel WJ, van den Born BJ, de Bruijne EL, Deinum J, Kerstens MN, Arnoldus JH, Woittiez AJ, Wijbenga JA, Zietse R, Danser AH, van den Meiracker AH. Determinants of blood pressure reduction by eplerenone in uncontrolled hypertension. J Hypertens 2013; 31: 404-413.

14 Guo C, Martinez-Vasquez D, Mendez GP, Toniolo MF, Yao TM, Oestreicher EM, Kikuchi T, Lapointe N, Pojoga L, Williams GH, Ricchiuti V, Adler GK. Mineralocorticoid receptor antagonist reduces renal injury in rodent models of types 1 and 2 diabetes mellitus. Endocrinology 2006; 147: 5363-5373.

15 Oyamada N, Sone M, Miyashita K, Park K, Taura D, Inuzuka M, Sonoyama T, Tsujimoto $\mathrm{H}$, Fukunaga $\mathrm{Y}$, Tamura N, Itoh H, Nakao K. The role of mineralocorticoid receptor expression in brain remodeling after cerebral ischemia. Endocrinology 2008; 149: 3764-3777.

16 Quinkler M, Zehnder D, Eardley KS, Lepenies J, Howie AJ, Hughes SV, Cockwell P, Hewison M, Stewart PM. Increased expression of mineralocorticoid effector mechanisms in kidney biopsies of patients with heavy proteinuria. Circulation 2005; 112 : 1435-1443.

17 Shibata S, Mu S, Kawarazaki H, Muraoka K, Ishizawa K, Yoshida S, Kawarazaki W, Takeuchi M, Ayuzawa N, Miyoshi J, Takai Y, Ishikawa A, Shimosawa T, Ando K, Nagase M, Fujita T. Rac1 GTPase in rodent kidneys is essential for salt-sensitive hypertension via a mineralocorticoid receptor-dependent pathway. J Clin Invest 2011; 121: 3233-3243.

18 Shibata S, Nagase M, Yoshida S, Kawarazaki W, Kurihara H, Tanaka H, Miyoshi J, Takai Y, Fujita T. Modification of mineralocorticoid receptor function by Rac1 GTPase: implication in proteinuric kidney disease. Nat Med 2008; 14: 1370-1376.

19 Simon AR, Vikis HG, Stewart S, Fanburg BL, Cochran BH, Guan KL. Regulation of STAT3 by direct binding to the Rac1 GTPase. Science 2000; 290: 144-147.

20 Wang H, Huang BS, Leenen FH. Brain sodium channels and ouabainlike compounds mediate central aldosterone-induced hypertension. Am J Physiol Heart Circ Physiol 2003; 285: H2516-H2523.

21 Zhang ZH, Yu Y, Kang YM, Wei SG, Felder RB. Aldosterone acts centrally to increase brain renin-angiotensin system activity and oxidative stress in normal rats. $A m \mathrm{~J}$ Physiol Heart Circ Physiol 2008; 294: H1067-H1074.

22 Xue B, Zhang Z, Roncari CF, Guo F, Johnson AK. Aldosterone acting through the central nervous system sensitizes angiotensin II-induced hypertension. Hypertension 2012; 60: 1023-1030.

23 Nakagaki T, Hirooka Y, Matsukawa R, Nishihara M, Nakano M, Ito K, Hoka S, Sunagawa K. Activation of mineralocorticoid receptors in the rostral ventrolateral 
medulla is involved in hypertensive mechanisms in stroke-prone spontaneously hypertensive rats. Hypertens Res 2012; 35: 470-476.

24 Nakano M, Hirooka Y, Matsukawa R, Ito K, Sunagawa K. Mineralocorticoid receptors/ epithelial $\mathrm{Na}(+)$ channels in the choroid plexus are involved in hypertensive mechanisms in stroke-prone spontaneously hypertensive rats. Hypertens Res 2012; 36: $277-284$

25 Fujita M, Kuwaki T, Ando K, Fujita T. Sympatho-inhibitory action of endogenous adrenomedullin through inhibition of oxidative stress in the brain. Hypertension 2005; 45: 1165-1172.

26 Kawakami-Mori F, Shimosawa T, Wang H, Ogura S, Mu S, Yatomi Y, Fujita T. NADPH oxidase-mediated Rac1 GTP activity is necessary for non-genomic actions of the mineralocorticoid receptor in the CA1 region of the rat hippocampus. Am J Physiol Endocrinol Metab 2012; 302: E425-E432.

27 Kawarazaki H, Ando K, Shibata S, Muraoka K, Fujita M, Kawarasaki C, Fujita T. Mineralocorticoid receptor-Rac 1 activation and oxidative stress play major roles in saltinduced hypertension and kidney injury in prepubertal rats. J Hypertens 2012; 30: 1977-1985.

28 Queisser N, Amann K, Hey V, Habib SL, Schupp N. Blood pressure has only minor influence on aldosterone-induced oxidative stress and DNA damage in vivo. Free Radic Biol Med 2013; 54: 17-25.

29 Briet M, Schiffrin EL. Vascular actions of aldosterone. J Vasc Res 2013; 50: 89-99.

30 Zia AA, Kamalov G, Newman KP, McGee JE, Bhattacharya SK, Ahokas RA, Sun Y, Gerling IC, Weber KT. From aldosteronism to oxidative stress: the role of excessive intracellular calcium accumulation. Hypertens Res 2010; 33: 1091-1101.

31 Raheja P, Price A, Wang Z, Arbique D, Adams-Huet B, Auchus RJ, Vongpatanasin W. Spironolactone prevents chlorthalidone-induced sympathetic activation and insulin resistance in hypertensive patients. Hypertension 2012; 60: 319-325.

32 Crowley SD, Gurley SB, Herrera MJ, Ruiz P, Griffiths R, Kumar AP, Kim HS, Smithies O, Le TH, Coffman TM. Angiotensin II causes hypertension and cardiac hypertrophy through its receptors in the kidney. Proc Natl Acad Sci USA 2006; 103: 17985-17990.

33 Lavoie JL, Lake-Bruse KD, Sigmund CD. Increased blood pressure in transgenic mice expressing both human renin and angiotensinogen in the renal proximal tubule. Am J Physiol Renal Physiol 2004; 286: F965-F971.

34 Gurley SB, Riquier-Brison AD, Schnermann J, Sparks MA, Allen AM, Haase VH, Snouwaert JN, Le TH, McDonough AA, Koller BH, Coffman TM. AT1A angiotensin receptors in the renal proximal tubule regulate blood pressure. Cell Metab 2011; 13: 469-475.

35 Mamenko M, Zaika O, Ilatovskaya DV, Staruschenko A, Pochynyuk O. Angiotensin II increases activity of the epithelial $\mathrm{Na}+$ channel $(\mathrm{ENaC})$ in distal nephron additively to aldosterone. J Biol Chem 2012; 287: 660-671.

36 Padia SH, Howell NL, Siragy HM, Carey RM. Renal angiotensin type 2 receptors mediate natriuresis via angiotensin III in the angiotensin II type 1 receptor-blocked rat. Hypertension 2006; 47: 537-544.

37 Gao L, Wang W, Li H, Sumners C, Zucker IH. Effects of angiotensin type 2 receptor overexpression in the rostral ventrolateral medulla on blood pressure and urine excretion in normal rats. Hypertension 2008; 51: 521-527.

38 Martens JR, Wang D, Sumners C, Posner P, Gelband CH. Angiotensin II type 2 receptor-mediated regulation of rat neuronal K+ channels. Circ Res 1996; 79: 302-309.

39 AbdAlla S, Lother H, Quitterer U. AT1-receptor heterodimers show enhanced G-protein activation and altered receptor sequestration. Nature 2000; 407: 94-98.

40 AbdAlla S, Lother H, el Massiery A, Quitterer U. Increased AT(1) receptor heterodimers in preeclampsia mediate enhanced angiotensin II responsiveness. Nat Med 2001; 7: 1003-1009.

41 Nouet S, Amzallag N, Li JM, Louis S, Seitz I, Cui TX, Alleaume AM, Di Benedetto M, Boden C, Masson M, Strosberg AD, Horiuchi M, Couraud PO, Nahmias C. Transinactivation of receptor tyrosine kinases by novel angiotensin II AT2 receptorinteracting protein, ATIP. J Biol Chem 2004; 279: 28989-28997.

42 Zou Y, Akazawa H, Qin Y, Sano M, Takano H, Minamino T, Makita N, Iwanaga K, Zhu W, Kudoh S, Toko H, Tamura K, Kihara M, Nagai T, Fukamizu A, Umemura S, Iiri T, Fujita T, Komuro I. Mechanical stress activates angiotensin II type 1 receptor without the involvement of angiotensin II. Nat Cell Biol 2004; 6: 499-506.

43 Abadir PM, Periasamy A, Carey RM, Siragy HM. Angiotensin II type 2 receptorbradykinin B2 receptor functional heterodimerization. Hypertension 2006; 48: 316-322.

44 Yasuda N, Akazawa H, Ito K, Shimizu I, Kudo-Sakamoto Y, Yabumoto C, Yano M, Yamamoto R, Ozasa Y, Minamino T, Naito AT, Oka T, Shiojima I, Tamura K, Umemura S, Paradis P, Nemer M, Komuro I. Agonist-independent constitutive activity of angiotensin II receptor promotes cardiac remodeling in mice. Hypertension 2012; 59: 627-633.

45 Calhoun DA. Hyperaldosteronism as a common cause of resistant hypertension. Annu Rev Med 2013; 64: 233-247. 